\title{
KEBIJAKAN FORMULASI SAKSI PELAKU YANG BEKERJASAMA \\ (JUSTICE COLLABORATOR) SEBAGAI ALASAN PERINGANAN \\ PIDANA DALAM RANGKA PEMBARUAN HUKUM PIDANA \\ NASIONAL
}

\begin{abstract}
Rahmi Dwi Sutanti ${ }^{1}$, Barda Nawawi Arief ${ }^{2}$,
ABSTRAK

Penelitian ini bertujuan untuk mengetahui kebijakan formulasi hukum pidana tentang Saksi Pelaku yang Bekerjasama (Justice Collaborator) sebagai alasan peringanan pidana saat ini. Tujuan lainnya adalah mengetahui kebijakan formulasi hukum pidana tentang Saksi Pelaku yang Bekerjasama (Justice Collaborator) sebagai alasan peringanan pidana yang akandatang. Penelitian ini merupakan penelitian hukum normatif yang dianalisis menggunakan analisis kualitatif. Hasil penelitian menunjukan bahwa kebijakan formulasi hukum pidana saat ini mengenai Saksi Pelaku yang Bekerjasama dapat ditemukan dalam beberapa peraturan, yang telah merumuskan adanya peringanan pidana. Data lainnya menjukan bahwa Kebijakan formulasi hukum pidana yang akan datang mengenai Saksi Pelaku yang Bekerjasama sebagai alasan peringanan pidana dapat dilakukan dengan memperhatikan Pengertian.
\end{abstract}

Kata Kunci: kebijakan, Justice Collaborator, keringanan pidana,

\begin{abstract}
This study aims to determine the policy formulation of the criminal law of the Cooperating Witness Actors (Justice Collaborator) as the reason for the current criminal mitigation. Another aim was to determine the formulation of criminal law policy of the Cooperating Witness Actors (Justice Collaborator) as a reason for criminal mitigation come. This research is a normative law were analyzed using qualitative analysis. The results showed that the policy formulation of the current criminal law regarding Witness Collaborating Actors can be found in some of the rules, which have formulated their criminal mitigation. Other data menjukan that the criminal law policy formulation that will come about as a Cooperating Witness Actors that reason criminal mitigation can be done by taking into account Understanding .
\end{abstract}

Keywords: policy, Justice Collaborator, lightening criminal,

\footnotetext{
${ }^{1}$ Mahasiswa Program Studi Magister IImu Hukum UNDIP

${ }^{2}$ Dosen Program Studi Magister Ilmu Hukum UNDIP
} 


\section{I.PENDAHULUAN}

\section{Latar Belakang}

Penanganan tindak pidana korupsi, sebagai salah satu tindak pidana terorganisir, memunculkan istilah baru Justice Collaborator. Istilah yang sering disandingkan dengan whistleblower ini, mendorong Mahkamah Agung untuk menerbitkan Surat Edaran (SEMA) Nomor 4 Tahun 2011, untuk memberikan instruksi bagi Para Hakim agar memberikan perlakuan khusus bagi orangorang yang dapat dikategorikan sebagai Pelapor Tindak Pidana dan Saksi Pelaku yang Bekerjasama, antara lain dengan memberikan keringanan pidana dan/atau bentuk perlindungan lainnya.

SEMA Nomor 4 Tahun 2011, memberikan batasan Saksi Pelaku yang Bekerjasama (Justice Collaborator), adalah salah satu pelaku tindak pidana terorganisir, mengakui kejahatan yang dilakukannya, bukan pelaku utama dalam kejahatan tersebut serta memberikan keterangan sebagai saksi di dalam proses peradilan.

Alasan peringanan pidana yang selama ini dikenal dalam Kitab Undang-Undang Hukum Pidana (KUHP) Indonesia, adalah Percobaan sebagaimana diatur di dalam Pasal 53; dan Pembantuan sebagaimana diatur dalam Pasal 56-57. Selain mengenai Percobaan dan Pembantuan, alasan peringanan pidana juga ditemukan dalam pengaturan di luar KUHP, yaitu terkait dengan anak yang berkonflik dengan hukum, sebagaimana diatur dalam Undang-Undang Nomor 11 Tahun 2012 tentang Sistem Peradilan Pidana Anak.

Mengetahui adanya desakan dari dunia Internasional yang tertuang dalam berbagai hasil konvensi internasional, yaitu UNCAC 2003 dan UNCATOC 2000 untuk memberikan peringanan pidana bagi Saksi Pelaku yang Bekerjasama (Justice Collaborator); perkembangan KUHP asing yang telah memasukkan unsur "kerjasama" seperti yang dimaksud dalam

Saksi Pelaku yang Bekerjasama (Justice Collaborator), sebagai alasan peringanan pidana (Norwegia dan Portugal); dan 


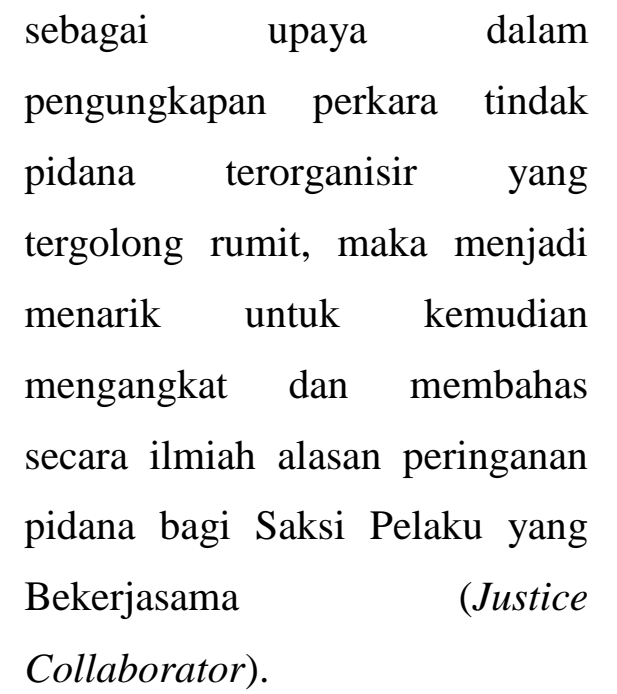

\section{Permasalahan}

Berdasarkan uraian latar belakang tersebut, maka rumusan masalah yang muncul dalam penulisan tesis ini adalah sebagai berikut:

1. Bagaimana

kebijakan formulasi hukum pidana tentang Saksi Pelaku yang Bekerjasama

(Justice

Collaborator) sebagai alasan peringanan pidana saat ini?

2. Bagaimana kebijakan formulasi hukum pidana tentang Saksi Pelaku yang Bekerjasama (Justice Collaborator) sebagai alasan peringanan pidana yang akan datang?

\section{Tinjauan Pustaka}

\section{a. Pembaruan Hukum Pidana Indonesia}

$\begin{array}{ccc}\text { Hukum } & \text { pidana } & \text { yang } \\ \text { merupakan } & \text { bagian } & \text { dari }\end{array}$

keseluruhan hukum yang berlaku di suatu negara, oleh Moeljatno didefinisikan sebagai dasar dan aturan untuk : ${ }^{31}$

a. Menentukan perbuatan yang dilarang disertai ancaman berupa pidana tertentu bagi yang melanggar.

b. Menentukan kapan dan dalam hal apa pidana dapat dijatuhkan kepada mereka yang melanggar larangan tersebut.

c. Menentukan dengan cara bagaimana pengenaan pidana dapat dilakukan terhadap orang yang disangka telah melanggar larangan tersebut.

Melakukan pembaruan hukum (law reform) khususnya pembaruan hukum pidana (penal reform), pada hakikatnya tidak hanya mengganti rumusan pasal akan tetapi membangun atau memperbarui pokokpokokpemikiran ide dasarnya ${ }^{4}$. Upaya melakukan pembaharuan hukum pidana pada hakikatnya $:^{5}$

a. Merupakan bagian dari kebijakan

\footnotetext{
${ }^{3}$ Moeljatno, Asas-Asas Hukum Pidana, (Jakarta : Rineka Cipta, 2008), hlm.1.

${ }^{4}$ Barda Nawawi Arief, Pembaharuan Hukum Pidana dalam Perspektif KajianPerbandingan, (Bandung : Citra Aditya Bakti, 2005), hlm. 1.

3 Ibid, hlm. 3.
} 
(upaya rasional) untuk memperbarui substansi hukum (legal substance) dalam rangka lebih mengefektifkan penegakan hukum.

b. Merupakan bagian dari kebijakan (upaya rasional) untuk memberantas/menanggulangi kejahatan dalam rangka perlindungan masyarakat.

c. Merupakan bagian dari kebijakan (upaya rasional) untuk mengatasi masalah sosial dan masalah kemanusiaan dalam rangka mencapai/menunjang tujuan nasional (yaitu "social defence" dan "social welfare").

d. Merupakan upaya peninjauan dan penilaian kembali (reorientasi dan reevaluasi) pokok-pokok pemikiran, ide-ide dasar, atau nilai-nilai sosio-filosofik, sosiopolitik, dan sosio-kultural yang melandasi kebijakan kriminal dan kebijakan (penegakan) hukum pidana selama ini.

Pembaruan hukum pidana (penal reform) merupakan kegiatan yang berlanjut, terus-menerus (kontinyu) dan tak kenal henti (suistanable). Pembaruan hukum pidana pada hakikatnya harus dilakukan dengan pendekatan yang

berorientasi pada kebijakan ("policyoreientedapproach") dan sekaligus pendekatan yang berorientasi pada nilai ("value-oriented approach"). Pembaruan dilakukan dengan berdasarkan padakebijakan, mengingat pada hakikatnya pembaruan merupakan bagian dari kebijakan atau "policy". Pembaruan hukum pidana (penal reform) merupakan bagian dari kebijakan atau politik hukum pidana (penal policy). Di dalam setiap kebijakan terkandung pertimbangan nilai, oleh karena itu pembaruan hukum pidana harus didasarkan pada pendekatan nilai. $^{6}$

\section{B. Kebijakan Formulasi sebagai Bagian dari Kebijakan Hukum Pidana}

Salah satu hal yang ingin dicapai dalam hukum pidana adalah mengenai penanggulangan kejahatan. Sudarto, mengemukakan bahwasanya suatu usaha yang rasional dari masyarakat dalam menanggulangi kejahatan dapat disebut dengan politik kriminal ataupun kebijakan kriminal.

\footnotetext{
${ }^{4}$ Barda Nawawi Arief, Bunga Rampai Kebijakan Hukum Pidana : PerkembanganPenyusunan Konsep KUHP Baru, (Jakarta : Kencana, 2010), hlm.29.
} 
Politik kriminal dapat juga diartikan dalam arti sempit, lebih luas, dan paling luas. ${ }^{7}$

Pembangunan harus diusahakan terwujud pada ketiga tahap kebijakan penegakan hukum pidana, yang meliputi tahap formulasi, aplikasi, dan eksekusi. Inilah yang dimaksud dengan penegakan hukum pidana merupakan bagian integral dari kebijakan sosial. Menurut Muladi, inilah yang menunjukkan pengertian social engineering by criminal law ${ }^{8}$.

Merumuskan asas dalam hukum pidana juga merupakan langkah kriminalisasi. Karena dengan dibentuknya asas tersebut, maka akan menentukan perbuatan-perbuatan mana yang kemudian dapat dipandang sebagai suatu tindak pidana atau dapat dimintai pertanggungjawabannya.

\section{Alasan}

\section{Peringan}

an

Pidana

dalam

${ }^{5}$ Sudarto, Kapita Selekta Hukum Pidana, (Bandung : Penerbit Alumni, 1981), halm.113-

6 Muladi, Kapita Selekta Sistem Peradilan Pidana, (Semarang: Badan Penerbit Universitas Diponegoro, 2004), hlm. 14.

\section{Hukum}

Pidana

Tujuan pemidanaan saat ini tidak dapat hanya dilihat sebagai aspek pembalasan (absolut) ataupun aspek pencegahan (relatif). Barda Nawawi Arief mengungkapkan perkembangan tujuan pidana sebagai berikut $:^{9}$

a. Dilihat dari aspek Perlindungan terhadap kejahatan, maka tujuan pidana adalah penanggulangan kejahatan.

b. Dilihat dari aspek Perlindungan terhadap pelaku, maka tujuan pidana adalah Perbaikan si Pelaku (mengubah tingkah laku).

c. Dilihat dari aspek Perlindungan terhadap Penyalahgunaan

Sanksi/Reaksi, maka tujuan pidana adalah mengatur/membatasi kesewenangan penguasa dan warga masayarakat.

d. Dilihat dari aspek Perlindungan terhadap keseimbangan kepentingan/nilai yang

${ }^{9}$ Barda Nawawi Arief, Tujuan dan Pedoman Pemidanaan Perspektif PembaharuanHukum 
terganggu, maka tujuan

pidana

adalah

memelihara/memulihkan

keseimbangan masyarakat.

Alasan peringanan pidana dalam sistem peradilan pidana Indonesia, dapat dikelompokkan menjadi dua kelompok, yaitu :

a. Alasan Yuridis

Merupakan alasan peringanan pidana yang melihat keadaan objektif terjadinya suatu tindak pidana. alasan peringanan pidana yang merupakan alasan yuridis ini antara lain : Percobaan (Pasal 53 KUHP); Pembantuan (Pasal $56 \quad$ KUHP); Pertanggungjawaban pidana bagi Anak; dan pengembalian kerugian keuangan negara sebagaimana Pasal 4 UU No. 31 Tahun 1999.

b. Alasan Faktual

Merupakan alasan peringanan pidana yang melihat dari keadaan subjektif terjadinya tindak pidana, yaitu keadaankeadaan yang meliputi pelaku (kondisi pelaku) saat melakukan tindak pidana. Alasan peringanan pidana faktual ini biasanya nampak pada putusan Hakim sebagai "Hal yang Meringankan".

\section{Pemahamanan mengenai Saksi Pelaku yang Bekerjasama (JusticeCollaborator)}

Terdapat beberapa istilah untuk menyebut keterlibatan seorang pelaku kejahatan dalam pengungkapan kasus tindak pidana yang dilakukannya. Istilah-istilah tersebut antara lain Plea Bargaining, CrownWitness, Whistleblower, dan Justice Collaborator.

$$
\text { Plea Bargaining }
$$

memungkinkan terdakwa mengaku bersalahsebelum persidangan dimulai. Jika jaksa setuju, maka jaksa dapat

mengurangi dakwaan atau memberi rekomendasi kepada pengadilan agar menjatuhkan pidana yang lebih ringan. ${ }^{10}$

Crown Witness atau Saksi mahkota dikenal dalam praktikpengadilan di Nederland, yaitu salah seorang terdakwa yang paling ringan peranannya dalam pelaksanaan kejahatan itu, misalnya delik narkoba atau terorisme, dikeluarkan dari daftar

8 Indriyanto Seno Adji, Humanisme dan Pembaruan Penegakan Hukum (Jakarta: Kompas, 2009), hal 155. 
terdakwa dan dijadikan saksi.

Dasar hukumnya ialah asas oportunitas yang ada di tangan jaksa untuk menuntut atau tidak menuntut seseorang ke pengadilan baik dengan syarat maupun tanpa syarat.

Seorang Whistleblower seringkali dipahami sebagai saksi pelapor. Istilah dalam bahasa Inggris tersebut diartikan "peniup peluit" yang dimaknai sebagai pelaku kriminal yang membongkar kejahatan. ${ }^{11}$

Justice Collaborator adalah setiap tersangka yang terlibatorganisasi kejahatan dan telah melakukan suatu tindak pidana, baik atas inisiatif sendiri maupun atas permintaan aparatur hukum bekerja sama dengan penegak hukum untuk menemukan alat-alat bukti dan barang bukti sehingga penyidikan dan penuntutan dapat berjalan efektif. ${ }^{11}$

\section{I.5 Metodologi}

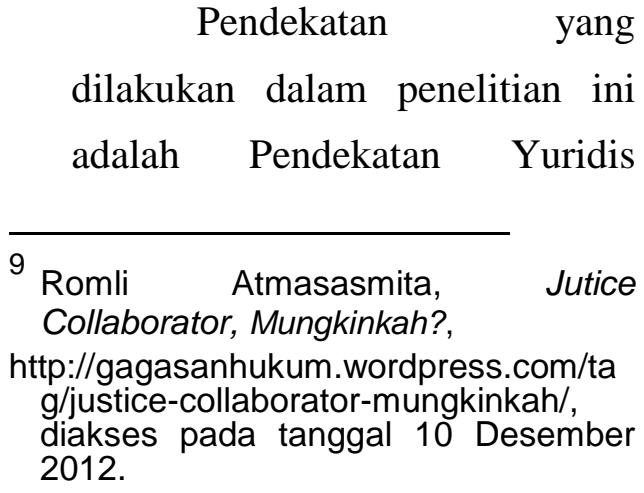

Normatif atau Doktrinal.

Penelitian yuridis normatif yang dimaksud disini adalah penelitian terhadap taraf sinkronisasi vertikal dan horizontal 1212 . Spesifikasi penelitian ini adalah Penelitian Deskriptif Analitis (kualitatif). Jenis data yang digunakan adalah data sekunder, dengan rincian berupa Bahan Hukum Primer, terdiri dari peraturan perundang-undangan yang mengandung kemungkinan adanya penerapan JusticeCollaborator sebagai alasan peringanan pidana, dan putusan hakimdengan terdakwa Agus Condro Prayitno; Bahan Hukum Sekunder, terdiri dari tulisan-tulisan atau pendapatpendapat pakar hukum pidana; dan, Bahan Hukum Tersier, terdiri dari kamus, dan tulisantulisan dalam jurnal hukum.

\section{B. HASIL PENELITIAN DAN PEMBAHASAN}

1. Kebijakan

Formulasi Hukum Pidana tentang Saksi Pelaku yang Bekerjasama (Justice Collaborator) Sebagai

\footnotetext{
${ }^{12}$ Soerjono Soekanto dan Sri Mamudji, Penelitian Hukum Normatif, Suatu TinjauanSingkat, (Jakarta : PT. Raja Grafindo Persada, 2004), hlm.74.
} 
Alasan Peringanan Pidana

Saat Ini

Undang-Undang
Nomor 8 Tahun 1981
tentang Hukum Acara
Pidana, merumuskan
pengertian mengenai Saksi,
di dalam Pasal 1 angka 26,
sebagai orang yang dapat
memberikan keterangan
guna kepentingan

penyidikan, penuntutan dan

peradilan tentang suatu

perkara pidana yang ia

dengar sendiri, ia lihat

sendiri dan ia alami sendiri.

Beberapa peraturan perundang-undangan $\quad \mathrm{di}$ Indonesia memberikan tempat bagi Saksi sebuah tindak pidana, antara lain :

a. Undang-Undang

Nomor 39 Tahun 1999 tentang Hak Asasi Manusia

b. Undang-Undang

Nomor 20 Tahun 2001

tentang Perubahan Atas

Undang-Undang

Nomor 31 Tahun 1999

tentang Pemberantasan

Tindak Pidana Korupsi

c. Undang-Undang

Nomor 15 Tahun 2003 tentang Penetapan

Perpu Nomor 1 Tahun 2002 tentang

Pemberantasan Tindak

Pidana Terorisme, menjadi UndangUndang

d. Undang-Undang

Nomor 21 Tahun 2007 tentang Tindak Pidana Perdagangan Orang

e. Undang-Undang Nomor 35 Tahun 2009 tentang Narkotika

f. Undang-Undang Nomor 8 Tahun 2010 tentang Pencegahan dan Pemberantasan Tindak Pidana Pencucian Uang 9

Pemidanaan untuk pelaku kejahatan, dapat dikelompokkan menjadi tiga, yaitu :

a. Dipidana sama dengan

Sebagaimana diatur dalam Pasal 55 Ayat (1) KUHP.

b. Dipidana lebih ringan

Sebagaimana diatur dalam Pasal 53 dan Pasal 56 KUHP. Selain itu, di luar KUHP, peringanan pidana diberikan bagi pelaku tindak pidana di bawah umur, sebagaimana diatur dalam UU No. 11 Tahun 2012 tentang Sistem 
Peradilan Pidana Anak; dan Pasal 4 Undang-Undang Nomor 31 Tahun 1999 tentang Pemberantasan tindak pidana korupsi, sebagaimana telah diubah dengan UndangUndang Nomor 20 Tahun 2001, yang menegaskan kemungkinan pemberian pidana yang lebih ringan bagi pelaku tipikor yang telah mengembalikan kerugian negara.

c. Dipidana lebih berat

Sebagaimana diatur dalam Pasal 63, 64, dan 65 KUHP (Perbarengan); dan Pasal Pasal 486, 487, dan 488 KUHP (Pengulangan). Perumusan alasan yang meringankan pidana di dalam KUHP, hanya mencakup Percobaan, sebagaimana dirumuskan dalam Pasal 53; dan Pembantuan sebagaimana dirumuskan dalam Pasal 56. Keberadaan Saksi Pelaku yang Bekerjasama untuk meringankan pidana belum dikenal dalam sistem KUHP Indonesia saat ini.

SEMA ini dibentuk untuk mewadahi peran serta masyarakat yang diberikan untuk menanggulangi tindak pidana tertentu yang bersifat serius seperti tindak pidana korupsi, terorisme, tindak pidana narkotika, tindak pidana pencucian uang, perdagangan orang, maupun tindak pidana lainnya yang bersifat terorganisir ${ }^{13}$. Saksi Pelaku yang Bekerjasama diterangkan sebagai salah satu pelaku tindak pidana tertentu sebagaimana dimaksud dalam SEMA ini, mengakui kejahatan yang dilakukannya, bukan pelaku utama dalam kejahatan tersebut serta memberikan keterangan sebagai saksi di dalam proses peradilan. Bentuk perlakuan yang dapat diberikan Hakim, adalah

1. Menjatuhkan pidana percobaan bersyarat khusus; dan/atau

2. Menjatuhkan pidana penjara yang paling ringan di antara terdakwa

lainnya yang terbukti bersalah dalam perkara yang dimaksud Pemberian perlakuan khusus dalam bentuk keringanan pidana, harus dilakukan hakim dengan tetap wajib

\footnotetext{
${ }^{13}$ Djoko Sarwoko, Reward Bagi "Whistle Blower" (Pelapor Tindak Pidana) dan "JusticeCollaborator" (Saksi Pelaku yang Bekerja Sama) dalam Perkara Tindak Pidana Tertentu,Rakernas Mahkamah Agung 2011, hlm. 3.
} 
memperhatikan rasa keadilan

masyarakat.

Meskipun ketentuan dalam SEMA ini bersifat internal dalam tembaga peradilan sehringga tidak dapat diterapkan dalam lembaga lain, akan tetapi langkah pembaruan Mahkamah Agung ini telah membuka jalan yang masih tertutup dalam kaitannya perhatian bagi Saksi Pelaku yang Bekerjasama (Justice Collaborator).

\section{A.2.4 Peraturan Bersama antara} Menkumham, Jaksa Agung, Kapolri, KPK, dan LPSK mengenai Perlindungan Bagi Pelapor, Saksi Pelapor, dan Saksi Pelaku yang Bekerjasama Pada tanggal 14

Desember 2011, diterbitkanlah Peraturan Bersama antara Menteri Hukum dan Hak Asasi Manusia Republik Indonesia (Nomor M.HH11.HM.03.02.TH.2011), Jaksa Agung Republik Indonesia (Nomor PER045/A/JA/12/2011), Kepala Kepolisian Negara Republik Indonesia (Nomor 1 Tahun 2011), Komisi Pemberantasan Korupsi Republik Indonesia
(Nomor

KEPB-02/0155/12/2011), dan Ketua Lembaga Perlindungan Saksi dan Korban Republik Indonesia (Nomor 4 Tahun 2011), tentang Perlindungan Bagi Pelapor, Saksi Pelapor dan Saksi Pelaku yang Bekerjasama.

Peraturan Bersama ini memberikan batasan definisi terhadap istilah Saksi Pelaku yang Bekerjasama sebagai saksi yang juga sebagai pelaku suatu tindak pidana yang bersedia membantu aparat penegak hukum untuk mengungkap suatu tindak pidana atau akan terjadinya suatu tindak pidana untuk mengembalikan aset-aset atau hasil suatu tindak pidana kepada negara dengan memberikan informasi kepada aparat penegak hukum serta memberikan kesaksian di dalam proses peradilan.

Hak-hak yang dapat
diperoleh Saksi Pelaku yang
Bekerjasama, sebagaimana diatur
dalam Peraturan Bersama ini
meliputi : perlindungan fisik dan
psikis; perlindungan hukum;
penanganan secara khusus; dan
penghargaan. Penghargaan yang


dapat diberikan kepada Saksi

Pelaku yang Bekerjasama, dapat berupa :

a. keringanan tuntutan hukuman, termasuk menuntut hukuman percobaan; dan/atau

b. pemberian remisi tambahan dan hak-hak narapidana lain sesuai peraturan perundangundangan yang berlaku apabila Saksi Pelaku

yang Bekerjasama adalah seorang narapidana.

Peraturan Bersama ini juga memberikan pengaturan mengenai tata cara pemberian hak; pembatalan hak tersebut; maupun ketentuan lainyang sifatnya teknis terkait dengan keberadaan Saksi Pelaku yang Bekerjasama.

${ }^{14}$ Yurisprudensi peradilan di Indonesia telah mencatatkan putusan kasus yang dinilai oleh publik terkait dengan Saksi Pelaku yang

Bekerjasama, salah satunya adalah kasus Agus Condro.

Agus Condro Prayitno diajukan ke persidangan bersama dengan empat terdakwa lainnya, yaitu Max Moein, Rusman Lumban Toruan, Poltak Sitorus ${ }^{14}$, dan

${ }^{14}$ Terdakwa atas nama Poltak Sitorus telah meninggal dunia, oleh karena itu terdapat alasan hapusnya pidana,
Williem Max Tutuarima.

Keempat terdakwa tersebut merupakan anggota DPR RI dari Fraksi PDI-P pada Komisi IX Periode Tahun 1999-2004. Para terdakwa terlibat dalam proses pemilihan Anggota Deputi Gubernur Senior Bank Indonesia yang dilaksanakan pada tanggal 8 Juni 2004 di gedung Nusantara I DPR RI, yang salah satu pesertanya adalah Miranda Swaray Gultom. $^{15}$

$$
\text { Para terdakwa }
$$

mendapat dakwaan alternatif dari Jaksa Penuntut Umum, sebagai berikut :

a. Kesatu :

Melanggar pasal 5 Ayat (2) jo. Pasal 5 Ayat (1) butir b Undang-Undang Nomor 31 Tahun 1999 tentang Pemberantasan Tindak Pidana Korupsi sebagaimana telah diubah dengan Undang-Undang Nomor 20 Tahun 2001 tentang Perubahan atas Undang-Undang Nomor 31 Tahun 1999 tentang sehingga tersisa empat terdakwa dalam persidangan kasus tersebut.

$$
\text { Putusan } \quad \text { No. }
$$


Pemberantasan Tindak

Pidana Korupsi jo. Pasal 55

Ayat (1) ke-1 KUHP.

b. Kedua :

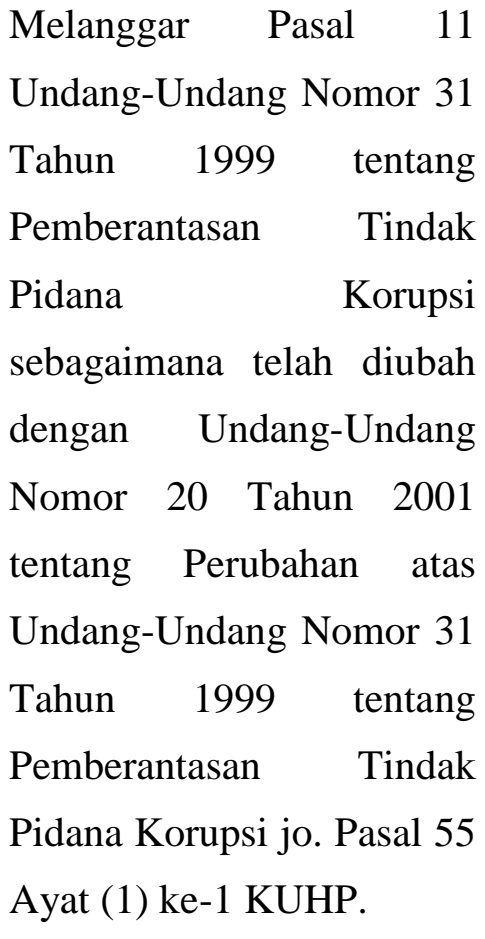

Berdasarkan dakwaan

alternatif tersebut, Majelis Hakim menilai fakta hukum yang terjadi di persidangan lebih tepat untuk membuktikan dakwaan Jaksa Penuntut Umum pada dakwaan kedua. Selain mempertimbangkan fakta-fakta hukum untuk membuktikan unsur dalam dakwaan, Majelis Hakim di dalam menjatuhkan putusan, juga mempertimbangan Nota Pembelaan Tim Penasihat Hukum Agus Condro yang tidak membantah atau keberatan dengan analisa yuridis
Jaksa Penuntut Umum di dalam tuntutan pidananya, namun hanya meminta kepada Majelis Hakim agar diberikan putusan yang berdimensi keadilan, mengingat terdakwa adalah Whistle Blower, yang didukung surat dari Lembaga Perlindungan Saksi dan Korban No.R.0706/1.3/LPSK/05/2011, tanggal 27 Mei 2011, yang intinya menyangkut keringanan hukuman.

$\begin{array}{ccc}\text { Majelis Hakim } & \text { juga } \\ \text { mempertimbangkan } & \text { "Hal yang }\end{array}$ Meringankan" sebelum menjatuhkan putusan, yaitu berupa :

a. Terdakwa mengakui terus terang;

b. Terdakwa bersikap sopan di persidangan;

c. Terdakwa menyesali perbuatannya;

d. Terdakwa belum pernah dihukum

e. Terdakwa telah menyerahkan uang yang diperoleh dari hasil kejahatan ke negara melalui KPK yaitu Rp. 100.000.000,- (seratus juta rupiah) untuk disetor ke Kas Negara dan menyerahkan 1 (satu) buah apartemen berikut dokumen kepemilikannya;

f. Terdakwa adalah sebagai Pelapor sehingga perkara korupsi penerimaan TC BII oleh anggota Komisi IX DPR RI periode tahun 1999-2004 dapat terungkap. 
Surat dari LPSK

menyebutkan peranan Agus Condro Prayitno adalah Whistle Blower. Akan tetapi, pertimbangan "mengakui terus terang", "menyesali perbuatannya", "menyerahkan hasil kejahatan", dan "sebagai pelapor yang mengungkap tindak pidana", mengindikasikan

adanya peran sebagai Saksi Pelaku yang Bekerjasama, meskipun istilah Saksi Pelaku yang Bekerjasama tidak disebut Majelis Hakim dalam putusannya.

Putusan pidana penjara yang dikenakan terhadap Agus Condro Prayitno dapat dikatakan lebih ringan bila dibandingkan dengan terdakwa lain dalam kasus yang sama. Dalam hal ini terlihat adanya peringanan pidana bagi pelaku penyertaan tindak pidana (deelneming). Merupakan hal yang kontras, mengingat terhadap pelaku penyertaan, pidananya diperberat.

Perkembangan

pemberian status Justice Collaborator dalam beberapa kasus hukum di Indonesia ditunjukkan dengan pemberian status tersebut bagi beberapa terpidana yang telah menjalani sebagian 1 hukumannya. Para terpidana yang kemudian bergelar Justice Collaborator ini antara lain, Tony Wong dalam kasus pembalakan liar; Mindo Rosalina Manulang dalam kasus suap Wisma Atlet Sumatera Selatan; dan yang terbaru adalah Vincentius dalam kasus penggelapan pajak PT. Asian Agri.

3. Kebijakan Formulasi Hukum Pidana tentang Saksi Pelaku yang Bekerjasama (Justice Collaborator) Sebagai Alasan Peringanan Pidana

\section{Yang Akan Datang}

Berdasarkan Pasal 37

Konvensi PBB Melawan Korupsi, orang-orang yang ikut serta dalam tindak pidana yang ditetapkan dalam 
Konvensi ini, yang telah memberikan informasi yang berguna kepada pejabat yang berwenang untuk tujuan penyelidikan dan pembuktian; dan untuk memberikan bantuan khusus dan faktual kepada pejabat yang berwenang dalam merampas hasil kejahatan dan mengembalikannya, wajib diberikan tindakan dukungan yang tepat, yaitu berupa mengurangi hukuman terdakwa (ayat 2); dan dilepaskannya saksi pelaku tersebut dari penuntutan (ayat $3)$.

Konvensi ini memuat ketentuan perlakuan bagi seseorang yang bekerjasama dengan pejabat penegak hukum, yaitu dalam Pasal 26. Tindakan yang tepat dalam mendorong partisipasi orang-orang dalam pengungkapan kejahatan terorganisir, salah satunya dilakukan dengan memberikan kemungkinan dalam kasus tertentu, untuk mengurangi hukuman terdakwa yang memberikan kerjasama substansial dalam penyidikan atau penuntutan suatu tindak pidana terorganisir. Selain itu, dirasa perlu pula untuk memberikan imunitas.

\section{a. Macedonia}

$$
\text { Undang-Undang }
$$

Perlindungan Saksi Macedonia tanggal 26 Mei 2005, menyebut istilah Justice Collaborator dalam Pasal 2 angka 2, dengan kriteria sebagai berikut :

a. Merupakan terdakwa, terpidana, atau anggota kelompok kriminal atau geng lainnya;

b. Berpartisipasi dalam melakukan tindak pidana;

c. Setuju untuk bekerjasama dengan badan-badan yang berwenang dalam penyelidikan, penuntutan, dan persidangan tindak pidana tersebut;

d. Dengan memberikan pernyataan dalam kapasitas sebagai saksi terkait dengan tindak pidana yang terorgansir.

Akan tetapi, bentuk perlakuan yang dapat diberikan bagi JusticeCollaborator menurut undang-undang ini hanyalah berupa menjagakerahasiaan identitas; 
menyediakan perlindungan

pribadi; perubahan tempat tinggal; dan, perubahan identitas.

Sedangkan perlakuan dalam hal peringanan pidana tidak nampak dalam undang-undang ini.

\section{b. Albania}

Undang-Undang Albania Nomor 9205 tertanggal 15 Maret 2004 yang berjudul Law on The Justice Collaborator and Witness Protection, memberikan pengertian mengenai Justice Collaborator dalam Pasal 2 huruf $b$. Berdasarkan pengertian yang ada dalam pasal tersebut, maka seorang Justice

Collaborator di Albania adalah seorang :

a. Terdakwa atau terpidana;

b. Mendapat perlindungan karena kerjasama, pemberitahuan, dan pernyataan yang dibuat selama proses pidana;

c. Berada pada kondisi bahaya dan ancaman yang nyata.

Beberapa hal yang dapat diberikan kepada justice collaboratordalam undangundang di Albania tersebut, sebagaimana disebutkan dalam Pasal 10, menunjukkan ketiadaan alasan peringanan pidana yang dapat diberikan pada seorang justice collaborator. Yang bersangkutan hanya berhak terhadap beberapa tindakan yang lebih mengarah kepada bentuk perlindungan.

\section{d. Norwegia}

Berdasarkan ketentuan dalam Pasal 58 dan Pasal 59 KUHP Norwegia, dapat diketahui bahwa KUHP Norwegia menunjukkan adanya pengurangan pidana bagi :

1) Pelaku kejahatan penyertaan;

2) Peranan dalam penyertaan tersebut sangat tergantung dengan orang lain, ataupun kadar penyertaannya kecil;

3) Sebelum mengetahui dirinya menjadi tersangka telah mencegah akibat yang timbul atau memperbaiki kerusakan dari perbuatannya; dan

4) Membuat pengakuan secara berterus-terang.

Unsur-unsur tersebut menunjukkan beberapa esensi Saksi Pelaku yang Bekerjasama, hanya saja pengaturan yang ada dalam KUHP Norwegia ini belum menyebut peranannya bagi pengungkapan kasus lain yang terkait dengan yang pelaku tersebut lakukan. Oleh karena itu, 
belum tepat apabila dikatakan

Saksi Pelaku yang Bekerjasama.

\section{e. Portugal}

Ketentuan mengenai peringanan pidana sebagaimana disebutkan dalam Pasal 72 KUHP Portugal, telah mengandung beberapa unsur Saksi Pelaku yang Bekerjasama, yaitu :

1) Adanya kondisi sebelum, pada saat, ataupun setelah tindak pidana dilakukan, yang menghilangkan sifat melawan hukumnya tindak pidana, kesalahan dari si pelaku tindak pidana, atau perlunya pidana dijatuhkan. Keadaan setelah terjadinya tindak pidana bisa berupa pengakuan tanpa paksaan dari si pelaku tindak pidana itu sendiri.

2) Unsur sikap pelaku tindak pidana yang menunjukkan adanyapenyesalan dan upayanya untuk memperbaiki kerusakan yang ditimbulkan.

\section{f. Jepang}

KUHP Jepang memuat
dua hal yang esensinya
mendekati Saksi Pelaku yang
Bekerjasama, yaitu Surrender

(menyerahkan diri), sebagaimana disebutkan dalam Pasal 42; dan Confessions

(pengakuan), sebagaimana disebutkan dalam Pasal 173. Hanya saja dalam hal Saksi Pelaku yang Bekerjasama, menyerahkan diri dan pengakuan saja tidak cukup, melainkan perlu adanya dorongan informasi yang diberikan untuk dapat mengungkap tindak pidana terorganisir yang melibatkan pihak lain.

Peringanan pidana bagi Saksi Pelaku yang Bekerjasama dirasa perlu untuk diformulasikan, dengan didasarkan pada alasan-alasan sebagai berikut :

a. Penegakan hukum pidana di Indonesia telah mulai memperhatikan peranan Saksi dalam pengungkapan kasus, termasuk di dalamnya adalah Saksi Pelaku yang Bekerjasama.

b. Eksistensi Saksi Pelaku yang Bekerjasama di Indonesia diakomodir dalam UndangUndang Perlindungan Saksi dan Korban (dengan tidak memberikan sebutan istilah); Surat Edaran Mahkamah 
Agung (bersifat terbatas hanya untuk Para Hakim); dan Peraturan Bersama antara Menkumham, Jaksa Agung, Kapolri, KPK, dan Ketua LPSK (sudah mulai mencakup prosedural perlakuan bagi Saksi Pelaku yang Bekerjasama).

c. Meskipun peraturan-peraturan yang telah mengakomodir perlakuan bagi Saksi Pelaku yang Bekerjasama mengisyaratkan adanya peringanan pidana, akan tetapi dalam induk hukum pidana di Indonesia (KUHP) belum merumuskan alasan peringanan pidana dalam hal peran Saksi Pelaku yang Bekerjasama.

d. Analisis terhadap putusan Agus Condro Prayitno menunjukkan adanya penyertaan dalam tindak pidana yang dilakukan, akan tetapi mendapat putusan yang lebih ringan dibandingkan beberapa terdakwa dalam rangkaian kasus korupsi tersebut, karena peranannya dalam pengungkapan kasus serta sikapnya yang menunjukkan penyesalan dan berusaha memperbaiki keadaan. Dengan demikian, esensi Saksi Pelaku yang Bekerjasama telah terlihat, dengan penegasan pula adanya peringanan terhadap suatu penyertaan tindak pidana.

e. Terdapat pula beberapa terpidana kasus yang belakangan disebut sebagai Saksi Pelaku yang Bekerjasama, sehingga peringanan pidana yang dapat diberikan adalah berupa remisi dan pembebasan bersyarat.

f. Dunia internasional telah mulai menaruh perhatian dalam hal peranan Saksi Pelaku yang Bekerjasama, yaitu dalam beberapa Konvensi dan perumusan undang-undang maupun KUHP negara lain.

g. Pancasila sebagai simbol-simbol nilai moralitas asli Bangsa Indonesia, dijadikan patokan dalam melaksanakan sistem peradilan pidana. Termasuk dalam menentukan kebijakan untuk memberikan peringanan pidana bagi Saksi Pelaku yang Bekerjasama, harus didasarkan nilai-nilai Pancasila, salah satunya "hikmat kebijaksanaan" dalam sila keempat.

h. Salah satu kearifan yang 
terkandung dalam Pancasila

adalah Kearifan Religius, yang

memberi landasan agamis

dalam penentuan kebijakan.

Dalam hal ini, maka kearifan

religius agama Islam,

memberikan rambu-rambu di

dalam Al Quran dan Hadis.

Dalam hal Saksi Pelaku yang

Bekerjasama, terdapat Hadis

yang menunjukkan bahwa

setiap individu yang bersedia

memberikan kesaksiannya

sebelum diminta adalah saksi

yang paling baik. Sedangkan

dalam beberapa ayat Al Quran,

menunjukkan bahwa kepastian

penghukuman yang ditentukan

Allah SWT ternyata juga tetap

ada keringanannya.

i. Bentuk perwujudan ius constituendum berupa Konsep KUHP 2012 merumuskan alasan peringanan pidana antara lain berupa penyerahan diri dan adanya penyesalan, yang merupakan salah satu esensi Saksi Pelaku yang Bekerjasama, menunjukkan bahwa Konsep telah menyeimbangkan unsur obyektif dengan unsur subyektif suatu tindak pidana.
Selain itu, untuk memberikan perlakuan yang khusus bagi Saksi Pelaku yang Bekerjasama, UU Nomo 13 Tahun 2006 tentang Perlindungan Saksi dan Korban, juga telah menyiapkan draft

rancangan baru.

\section{KESIMPULAN DAN SARAN}

\section{Kesimpulan}

a. Kebijakan formulasi hukum pidana saat ini mengenai Saksi Pelaku yang Bekerjasama dapat ditemukan dalam beberapa peraturan, yang telah merumuskan adanya peringanan pidana. Akan tetapi, posisi pengaturan-

pengaturan tersebut belum memiliki posisi yang kuat. Apalagi mengingat analisis putusan yang menunjukkan esensi Saksi Pelaku yang Bekerjasama adalah "Turut Serta yang Diperingan", sehingga 
perlu memasukkannya

ke dalam induk hukum pidana.

b. Kebijakan formulasi hukum pidana yang akan datang mengenai

Saksi Pelaku yang Bekerjasama sebagai alasan peringanan pidana dapat dilakukan dengan memperhatikan

Pengertian; Tindak pidana yang dapat memunculkan Saksi Pelaku yang

Bekerjasama; serta Bentuk Peringanan Pidana yang Dapat Diberikan. Kebijakan formulasi dapat dilakukan dengan membuat Peraturan Pemerintah Pengganti Undang-Undang (Perpu) untuk merevisi KUHP (jangka pendek); maupun dengan menempatkannya dalam RKUHP untuk segera disahkan menjadi KUHP (jangka panjang).

\section{Saran}

a. Segera mengadakan formulasi hukum pidana mengenai Saksi Pelaku yang Bekerjasama sebagai alasan peringanan pidana, baik dalam bentuk Peraturan Pemerintah untuk merevisi KUHP, maupun dalam RKUHP dan segera mengsahkannya menjadi KUHP.

b. Mengadakan penelitian dan seminar terkait perkembangan posisi Saksi Pelaku yang Bekerjasama dalam hukum pidana, yang menunjukkan adanya "turut serta yang diperingan".

\section{KEPUSTAKAAN}

Moeljatno. Asas-Asas Hukum Pidana. Jakarta : Rineka Cipta, 2008.

Muladi Kapita Selekta Sistem Peradilan Pidana. Semarang : Badan 
Penerbit

Universitas

Diponegoro, 2004.

Nawawi Arief, Barda.

Pembaharuan

Hukum Pidana

dalam

PerspektifKajian

Perbandingan.

Bandung : Citra

Aditya Bakti,

2005.

---------. Tujuan dan

Pedoman

Pemidanaan

Perspektif

PembaharuanHuku

$m$ Pidana dan

Perbandingan

Beberapa Negara.

Semarang

:Percetakan

Oetama, 2009.

\section{Bunga Rampai}

Kebijakan Hukum

Pidana : Perkembangan

Penyusunan

Konsep KUHP

Baru. Jakarta :

Kencana, 2010.

Seno Adji, Indriyanto.

Humanisme dan

Pembaruan

Penegakan Hukum.

Jakarta: Kompas,

2009.
Sudarto. Kapita Selekta

Hukum Pidana. Bandung :

Penerbit Alumni, 1981.

Djoko Sarwoko. Reward

Bagi "Whistle

Blower" (Pelapor

Tindak Pidana)dan

"Justice

Collaborator"

(Saksi Pelaku yang

Bekerja Sama) dalam Perkara Tindak

Pidana Tertentu. Rakernas

MahkamahAgung 2011.

Romli Atmasasmita, Jutice

Collaborator, Mungkinkah?, http://gagasanhukum.wordpre ss.com/tag/justicecollaborator-mungkinkah/, diakses pada tanggal 10

Desember 2012.

Putusan No.

14/Pid.B/TPK/2011/PN.JKT.PST 